\title{
Analysis of Human Resources Performance Evaluation Instrument at X Health Centre in Malang
}

\section{Indah Nur Putri Pratiwi ${ }^{1}$, Sendhi Tristanti Puspitasari ${ }^{1}$, and Roesdiyanto ${ }^{2}$}

${ }^{1}$ Department of Public Health, Faculty of Sport Science, Universitas Negeri Malang, Malang, East Java, Indonesia

${ }^{2}$ Faculty of Sport Science, Universitas Negeri Malang, Malang, East Java, Indonesia

ORCID:

Sendhi Tristanti Puspitasari: https://orcid.org/0000-0003-1568-9384

\section{Abstract}

$X$ Health Centre is one of the health centres located in the Sukun sub-district of Malang, with a working area covering four villages. As a healthcare facility, $X$ Health Centre is expected to continuously improve the quality of its services and performance. However, over a period of three years, from 2016 to 2018, the performance and the level of community satisfaction of $X$ Health Centre has downgraded. The overall performance of the health centre depends on the total value of its employee performance. The employee performance can be determined by evaluating individual performance using performance evaluation instruments. Thus, the purpose of this study was to analyse the instrument for evaluating the performance of the employees of $\mathrm{X}$ Health Centre in Malang. This qualitative descriptive study used a case study design and a cross-sectional approach. The samples in this study were selected through purposive sampling techniques. Based on the results of the study, it was observed that the instrument for evaluating the performance of the employees of $X$ Health Centre does not meet the requirements stated in the Government Regulation of the Republic of Indonesia Number 30 of 2019 about the Performance Evaluation of Civil Servants.

Keywords: health centre, employee performance evaluation, employee performance evaluation instruments

\section{Introduction}

Malang City has an area of $110.06 \mathrm{~km}^{2}$ which is distributed into five sub-districts namely Kedungkandang, Sukun, Klojen, Blimbing, and Lowokwaru. Sukun Sub-district is the second largest district in Malang City and has a population of 194,321 inhabitants. Sukun Sub-district has three health centres as the health service facilities namely, Janti Health Centre, Cipto Mulyo Health Centre, and X Health Centre [1]. X Health Centre has four work areas with the highest population growth rate in the Mulyorejo Urban Village, 
so X Health Centre has a higher workload compared to the other two health centres in Sukun Sub-district [2].The organization needs to assess its performance to determine the benchmarks of success [3].

$X$ Health Centre as an organization certainly evaluated its performance. The performance evaluation of health centre was carried out by the Malang Public Health Office so that the performance evaluation of $X$ Health Centre was carried out by the Malang Public Health Office as stipulated in Malang Mayor Regulation Number 26 of 2016 about Position, Organizational Structure, Duties and Functions and Work Procedures of the Public Health Office [4]. The results of preliminary studies showed that within a period of three years, starting in 2016, X Health Centre was able to achieve a Health Centre Performance Evaluation with a score of 8.01 and then increased to 8.95 in 2017. However, this value has decreased by 0.65 between 2017 and 2018 to 8.3. Besides, the decrease in the level of patient's satisfaction level at $X$ Health Centre also happened consecutively during the last three years: $82.80 \%$; $81.46 \%$; and $80.50 \%$.

The decline in performance at $X$ Health Centre was a reflection of the decline in the performance of its human resources or staff. This occurred because the organizational performance was very dependent on the total performance of employees as the members of the organization [5]. Health service facilities must improve service quality through health service quality assurance by evaluating individual performance based on Individual Performance Indicators [6]. The performance evaluation carried out was one of the activities of Human Resources Management[HRM] which was conducted to increase company support and commitment in the organization [7]. The level of organizational success in assessing its employees would depend on the instruments used [8]. Based on the background explanation above, this study was conducted to analyse the instruments of human resources' performance evaluation at the $X$ Health Centre in Malang.

\section{Material and Method}

This research was a descriptive qualitative research with case study design using a cross-sectional approach. The informant was selected using the purposive sampling method by considering some criteria. The informant was the employee who performed performance evaluation or performance evaluation activities, knew the process and all preparations of human resources' performance evaluation, had the authority to supervise and place all work units, and had the authority to carry out the human resources' activities. 
In conclusion, the informant chosen in this study was the Head of Administration at $X$ Health Centre. The information was obtained using interviews about employee performance indicator and documentation methods including employee performance regulation at $X$ Health Centre Malang, manual of employee performance evaluation and employee performance evaluation report for three years ago to support the results of the interview. Interviews were conducted in a structured manner using interview guidelines. The results of the information obtained were analysed by using the qualitative method.

\section{Results}

The performance evaluation of human resources at $X$ Health Center was conducted by the Head and the Head of Administration of X Health Center. This activity was carried out routinely once a year, every December 31st. The evaluation was carried out in each unit of X Health Center, which employed staff entitled State Civil Apparatus. The legal basis used as a reference for carrying out performance evaluation at $\mathrm{X}$ Health Center was the Government Regulation of the Republic of Indonesia Number 46 of 2011 about Performance Evaluation of Civil Servants.

The human resource's performance evaluation at X Health Center was carried out using instruments in the form of employee performance evaluation forms that referred to the Government Regulation of the Republic of Indonesia Number 46 of 2011 about Performance Evaluation of Civil Servants. The performance evaluation instruments contained two main aspects: employee work goals and work behavior. There were several indicators used to assess employee work goals, namely:

1. Quantity: X Health Center measured the quantity aspect by comparing the achievement targets with the results achieved by employees within one year.

2. Quality: the quality aspect was assessed by looking at the quality of the work and how many mistakes made by the employee.

3. Time: the time aspect was seen by assessing how well the employee could manage the time provided to achieve the targeted results.

4. Cost: the cost aspect was associated with the budget required in each workload.

5. Attendance: the attendance aspect was not included in the indicators of employee work goals at $X$ Health Center. 
In addition to the aspect of the employee work goals, aspects of work behavior were also considered for evaluating employee performance. The following indicators were used to assess the employee work behavior at:

1. Service orientation: $X$ Health Center assessed the service orientation aspect by observing how well the employees prioritized the professional work beside their errand.

2. Commitment: $X$ Health Center assessed the commitment aspect by observing how loyal the employee was to the institution and how obedient they were in running the assigned regulations.

3. Work initiatives: $X$ Health Center had not yet created a framework for this aspect for the performance evaluation.

4. Ability: X Health Center assessed the ability aspect by observing the ability of employees to cooperate with their colleagues and seniors.

5. Motivation: X Health Center had not yet created a framework for this aspect for the performance evaluation.

6. Career Opportunities: X Health Center had not yet created a framework for this aspect for the performance evaluation.

7. Leadership: this aspect was applied for structural officials and not used for functional employees.

The employee work goals and work behaviour were assessed by assigning different weights. $X$ Health Centre set the weighting of the employee work goals at $60 \%$ and the work behaviour at $40 \% . \times$ Health Centre determined the employee performance categories as follows: [1] Very Good: 91-100; [2] Good: 76-90; [3] Not bad: 61-75; [4] Poor: 51-60; [5] Very poor: 0-50. The results of the performance evaluation were delivered to each employee concerned. If the employee concerned felt that the results of the performance evaluation were not appropriate, then he could defend himself. The results of the human resources performance evaluation at $X$ Health Centre were served as the basic reference for the promotion of employee positions and as the evaluation to find out what needed to be improved. 


\section{Discussion}

Performance evaluation was one of the activities in performance management as a series of Human Resource Management [HRM] activities to assess and evaluate individual performance [9]. The purpose of the performance evaluation was utilized as a basis for providing fair feedback [10]. Performance evaluation had a positive relationship with employee performance $[11,12]$ so every organization needed to improve the performance evaluation process for employees. The following is a description of the performance evaluation at $X$ Health Center:

Performance evaluation was carried out by a team formed to consider the promotion, transfer, and dismissal in positions, competency development as well as giving awards to civil servants [13]. The team could be formed from management officials, such as the Head of Health Center and the Head of the Administration [14]. Based on the findings of the study, the performance evaluation at X Health Center was conducted by the Head of Health Center and the Head of the Administration. This was in line with research conducted by Aisyah \& Hariani [2015] that the performance evaluation at the Rowosari Health Center was also conducted by the Head of the Health Center and Head of Administration [15].

Furthermore, $X$ Health Center had not yet referred to the latest regulation, the Government Regulation of the Republic of Indonesia Number 30 of 2019 about Performance Evaluation of Civil Servants. Besides, the reference that should be used as a guideline was the Decree of the Minister of Health of the Republic of Indonesia Number 857 / Menkes / SK / IX / 2009 about Guidelines for Health Human Resources' Performance Evaluation in Health Center. The change of rules was carried out to motivate employees to obtain as many "Good" criteria as possible during the performance evaluation process [16].

The timing of the performance evaluation of employees at $X$ Health Center was following the Government Regulation Number 30 of 2019 about Performance Evaluation of Civil Servants [13]. Every organization must avoid focusing on a single aspect only. In general, performance evaluation consists of several criteria, namely individual characteristics, behavioral characteristics, the achievement of objectives, development, and competence [17]. $X$ Health Center assessed the employee performance by using a performance evaluation form that referred to aspects of employee work goals and work behavior. Here are the details: 


\subsection{Employee work goals}

Employee work goals were set and agreed upon between employees and their superiors and realized in the form of individual work indicators [18]. Employee work goals were used as a benchmark for each activity of the position of a civil servant [19]. The following are some aspects of employee work goals:

\subsubsection{Quantity}

Quantity is the amount that must be completed [20]. The quantity was applied to determine the level of work performance of employees [Noermijati, 2013: 44]. Meanwhile, based on the Government Regulation Number 30 of 2019 about Performance Evaluation of Civil Servants, quantity is the amount of output of funds or benefits that must be present in each performance target. The quantity aspect was used as an indicator to find out an individual's performance in carrying out his work or task performance [21] as a reference for evaluating the performance of public service employees [22].

\subsubsection{Quality}

Quality is a qualitative measure of results that reflects how well a job is completed [23]. Quality here is the quality of output and or quality of benefits [13]. Quality is related to the quality of work results, such as neatness, accuracy, and error rate [20, 24]. The quality aspect can be observed from the suitability of work completed following established standards [25].

\subsubsection{Time}

Timeliness or punctuality is related to quantitative measures of being punctual in completing activities. The time measure is arranged based on a previous experience [23]. Timeliness also determines how fast the work can be accomplished [26]. Time is the standard time used to complete activities [13]. The use of time indicators in measuring employee performance has a significant relationship with the organizational performance [27]. 


\subsubsection{Cost}

Cost is a measure of employee performance to observe how well the employees can manage the budget provided [26]. Cost is the funds needed to complete activities [13]. The cost indicator in measuring employee performance has a significant relationship with the organizational performance [27]. The evaluation of the cost aspect refers to the effectiveness of costs, such as the ability to gain profit and decrease improvidence [28].

\subsubsection{Attendance}

Attendance is the amount of employee attendance to go to work every month. Presence has a significant relationship with organizational performance, so it needs to be considered by the organization. Employee absences can occur due to several things such as illness, family problems, and employee's lack of commitment to work. Employee absence can harm organizational productivity [29], [30].

\subsection{Work behaviour}

Work behaviour is any behaviour, attitude, or action taken by the employee or that should not be carried out by the employee following laws and regulations [13]. Contextual performance can be used as a reference to evaluate the performance of public service employees [22]. Here is the explanation:

\subsubsection{Service orientation}

Service orientation is the attitude and work behaviour in providing the best service to the community, superiors, colleagues, related work units, or other agencies [13]. X Health Centre was a public service organization at the District level [31]. As a public service, it has the responsibility for carrying out services following the assigned rules and regulations [32].

\subsubsection{Commitment}

Commitment is the ability to align attitudes and actions to achieve organizational goals by prioritizing service interests rather than self-interest, and / or groups [13]. The view 
that work is a commitment can encourage employees to pursue their work [33]. This happens because commitment is a psychological condition that becomes the power for the individual to act and maintain the organization in which he works and creates bonds between individuals and the organization [34]. Commitment has a significant relationship with the organizational performance [34]. A leader can increase employee work commitment by providing a comfortable work atmosphere and provide motivation $[35,36]$

\subsubsection{Work initiative}

Work initiative is the willingness and ability to create new ideas for performance improvement, the willingness to help colleagues in need, to see problems as opportunities rather than threats, the willingness to work for the better, and enthusiasm [13]. Someone who has the initiative can take the right action without being given instructions in advance [37]. Individuals who have the initiative in working can adapt to the work environment [38]. Several aspects can increase employee initiatives, such as 1] Behaviour, it is related to the reciprocity of the results of initiative development, 2] Social pressure, it can increase initiative because it provides ways on how to maintain targets and priorities; 3] Ability, it can find various ways for improvement or development [39].

\subsubsection{Ability}

Psychological abilities consist of Intelligence Quotient [IQ] and cognitive abilities [knowledge and skills,40]. The ability aspect has a significant relationship with employee performance [41]. This means that the higher the ability of employees is, the higher the performance can become [42].

\subsubsection{Motivation}

Motivation is the thing that underlies someone to behave or not behave [43]. Motivation can occur either consciously or unconsciously. Motivation can be derived from the environment or the person himself [44]. The work result of an employee is a function of motivation, understanding, and ability to do work following the role or position in the organization [45]. Motivation has a significant relationship with employee performance [46]. These motivational aspects consist of appreciation, direction, and material stimulation [47]. Every person [employee] has a motivational axis that can be raised [48]. 
Bosses need to motivate employees to help the organization achieve its goals [43]. Providing incentives and giving attention has a significant relationship with employee motivation at Walenrang Health Centre in Luwu Regency [49].

\subsubsection{Career opportunities}

Career opportunities can encourage individuals to constantly improve learning about their potential so that they can improve their talent [50]. The organization plays an important role in career development or career planning for employees because career development can help the organization to improve individual performance and can overcome other competitive challenges [30]. Career opportunities is an external factor that can affect individual performance [51-53].

\subsubsection{Leadership}

Leadership is the ability and willingness to motivate and influence the member of an organization to achieve the organization's goals [13]. As a leader, it is expected to be able to motivate employees to carry out tasks [54]. Leadership has a significant relationship with employee performance [55-57].

Performance evaluation instruments are determined by weighting the percentage. Weighting the percentage emphasizes the individual performance indicators as a priority. Weighting the value of the employee work goals assessment aspects is set with the provisions of $60 \%$ for employee work goals and $40 \%$ for work behaviour [13]. The minimum weighting rate is $5 \%$; a weighting of $<5 \%$ indicates that the number of assigned Key Performance Indicator is too much [18]. The category of performance evaluation in the Government Regulation of the Republic of Indonesia Number 30 of 2019 about Performance Evaluation of Civil Servants is drawn as follows: [1] Very good: 110-120; [2] Good: 90-110; [3] Enough: 70-90; [4] Less: 50-70; [5] Very Poor: <50. The performance category in the Government Regulation mentioned before has higher value criteria in the hope of being able to increase the target achievement of the State Civil Apparatus [the employees,16].

The level of success of employees in carrying out their duties could be drawn by determining the performance evaluation method [8]. The employee performance evaluation method at $X$ Health Centre was a managerial evaluation method using a performance evaluation form. The managerial evaluation was top-down-designed and did not require active employee participation [26]. The evaluation was done by 
assessing employee performance during the last one-year period. The goal was to evaluate employee work performance objectively [8]. This was conducted by comparing employee performance with the expected output [employee work goals,57].

Performance evaluation in each position was the responsibility of superiors [58]. The Head of Health Centre and Head of Administration had the duty and authority to conduct employee performance evaluations [59]. If the performance evaluation was run well, then it could improve the performance and career development of employees [58]. Also, performance evaluation could assist the superiors in making decisions on either punishment or reward $[45,60]$. The results of the performance evaluation were used for 1] identifying and planning education or training needs; 2] developing competencies; 3] developing a career opportunity; 4] providing benefits; 5] considering the transfer and promotion; 6] giving rewards and sanctions or punishments following assigned rules and regulations; 7] following up on the problems found in the assessment of employee work goals and work behaviour [13].

Having an appraisal discussion with the employee was the final step in evaluating performance. Having an appraisal discussion with the employee was an activity of analysing and communicating the results of an employee performance evaluation that was assessed to know the performance expected by the organization [61-64]. Discussion on the results of employee performance evaluation at $X$ Health Centre was following the Government Regulation Number 30 of 2019 concerning Performance Evaluation of Civil Servants. A superior should also convey positive and negative things about the employee's performance in this discussion. Finally, a boss in this case must also discuss the targets to be achieved by employees in the following year $[65,66]$.

\section{Conclusion}

Based on the results of the study, it was obtained that the instrument for evaluating the performance of human resources at $X$ Health Centre did not meet the requirements as stated in the Government Regulation of the Republic of Indonesia Number 30 of 2019 about Performance Evaluation of Civil Servants. The legal basis used as a reference for carrying out performance evaluation at X Health Centre was the Government Regulation of the Republic of Indonesia Number 46 of 2011 about Performance Evaluation of Civil Servants. 


\section{Acknowledgement}

The authors would like to thank the support given by the Pharmacy Officers at Malang $X$ Health Centre.

\section{Conflict of Interest}

The authors declare that there is no conflict of interest.

\section{References}

[1] Badan Pusat Statistik Kota Malang. (2018). Kota Malang dalam Angka 2018 [Internet]. Malang. Retrieved from https://malangkota.bps.go.id/publication /download.html?nrbvfeve=ZjM5ODEyOGUwMzIxN2RiN2I3YWYOMzk5\&xzmn= aHROcHM6Ly9tYWxhbmdrb3RhLmJwcy5nby5pZC9wdWJsaWNhdGlvbi8yMDE5L zA4LzE2L2YzOTgxMjhIMDMyMTdkYjdiN2FmNDM5OS9rb3RhLW1hbGFuZy1kYW xhbS1hbmdrYSOyMDE5LmhObWw\{\%\}3D\&tw.

[2] Dinas Kesehatan Kota Malang. (2019). Puskesmas Mulyorejo. Retrieved from https: //dinkes.malangkota.go.id/2015/09/17/puskesmas-mulyorejo/.

[3] Prihantoro, A. (2017). Sumber Daya Manusia dan Peningkatan Kinerja. Semarang: Universitas Diponegoro.

[4] Malang, W. (2016). Peraturan Walikota Malang Nomor 26 Tahun 2016 tentang Kedudukan, Susunan Organisasi, Tugas dan Fungsi serta Tata Kerja Dinas Kesehatan [Internet]. 26 Tahun 2016 Malang; 2016. Retrieved from https://hukum.malangkota.go.id/download/Perwal/perwal2016/PERWAL-026TAHUN-2016-TENTANG-SO-DAN-TUSI-DINKES.pdf.

[5] Karak, S. and Sen, K. (2019). Performance Appraisal of Employee: A literature Review. Indonesian Journal of Applied Research, vol. 1, issue 6, pp. 1615-7.

[6] Wibowo, B. (2016). Peningkatan Akses Pelayanan Kesehatan yang Bekualitas. In Direktorat Jenderal Pelayanan Kesehatan. Retrieved from https://www.kemkes.go. id/resources/download/info-terkini/rakerkesnas_gel2_2016/Dirjen Yankes.pdf.

[7] Salau, O. P., et al. (2014). Modelling the Relationship Between Performance Appraisal Organization Productivity in Nigerian Public Sector. Int Jpurnal Res Manag, vol. 6 , issue 4, pp. 59-74.

[8] Pratiwi, I. N. P. and Yuwanita, N. (2018). Studi Observasi Alur Pelayanan dan Administrasi Puskesmas Mulyorejo Kota Malang. Malang: Universitas Negeri 
Malang.

[9] Ismail, F. and Andi, L. B. (2013). Faktor-Faktor yang Berhubungan dengan Pemanfaatan Fasilitas Pelayanan Kesehatan pada Ibu Hamil di Wilayah Kerja Puskesmas Gaya Baru Kecamatan Tellu Limpoe Kab. Bone. J Ilm Kesehat Diagnosis, vol. 1, issue 3, pp. 41-8.

[10] Anggraeni, R. (2019). Mutu Pelayanan Kefarmasian di Puskesmas. Sleman: Deepublish.

[11] Widiani, I. and Lisnawaty, L. (2015). Faktor yang Berhubungan dengan Pemanfaatan Pelayanan Kesehatan Ibu dan Anak di Puskesmas Tomia Timur Kelurahan Tongano Timur Kabupaten Wakatobi Tahun 2015. Retrieved from https://media.neliti.com/ media/publications/185663-ID-faktor-yang-berhubungan-dengan-pemanfaat.pdf.

[12] Mondy, R. W. and Noe, R. (2008). Human Resource Management. New Jersey: Pearson Prentice Hall.

[13] Kurtz, D. and Boone, L. E. (2015). Pengantar Bisnis Kotemporer (11 ${ }^{\text {th }}$ ed.). Jakarta: Salemba Empat.

[14] Flaniken, F. W. (2009). Performance Appraisal System in Higher Education: An Exploration of Christian Institution. Orlando: University of Central Florida.

[15] Sopiah, S. (2016). The Relationship between Performance Appraisal and Job Performance. Int J Acad Res Bus Soc Sci., vol. 6, issue 6, pp. 104-15.

[16] Girma, T., Lodesso, S. L. and Sorsa, G. (2016). The Effect of Performance Appraisal on Employee Performance: A Survey on Administrative Staff oh Hawassa University. IOSR J Bus Manag, vol. 3, issue 18, pp. 36-44.

[17] Presiden Republik Indonesia. (2019). Peraturan Pemerintah Republik Indonesia Nomor 30 Tahun 2019 tentang Penilaian Kinerja Pegawai Negeri Sipil. Retrieved from https://www.bkn.go.id/wp-content/uploads/2019/05/PP-Nomor-30Tahun-2019.pdf.

[18] Menteri Kesehatan Republik Indonesia. (2009). Keputusan Menteri Kesehatan Republik Indonesia Nomor 857/ Menkes/ SK/ IX/ 2009 tentang Pedoman Penilaian Kinerja Sumber Daya Manusia Kesehatan di Puskesmas. Retrieved from https: //www.persi.or.id/images/regulasi/kepmenkes/kmk8572009.pdf.

[19] Malang, W. (2018). Peraturan Wali Kota Malang Nomor 2 Tahun 2018 tentang Pedoman Penilaian Prestasi Kerja Pegawai Negeri Sipil. Retrieved from file:///C:/Users/L e n o v o/Downloads/a1f44f0a66be2dbd6b8f18beed2d4db4.pdf.

[20] Aisyah, Y. and Hriani, D. (2015). Penilaian Kinerja Pegawai Puskesmas Rowosari Kecamatan Tembalang, Semarang. Retrieved from https://media.neliti.com/media/ publications/95501-ID-penilaian-kinerja-pegawai-puskesmas-rowo.pdf. 
[21] BKPSDM Kabupaten Bintaro Selatan. (2019). Mari Mengenal Peraturan Pemerintah Nomor 30 Tahun 2019. Retrieved from https://bkpsdm.baritoselatankab.go.id/marimengenal-peraturan-pemerintah-nomor-30-tahun-2019/.

[22] Durai, P. (2010). Human Resource Management. Delhi: Dorling Kindsersley.

[23] Soemohadiwidjodjo, A. T. (2017). SOP \& KPI untuk UMKM \& Start Up. Jakarta: Raih Asah Sukses.

[24] BKN. (2016). Pedoman Penyusunan Standar Teknis Kegiatan Sasaran Kerja Pegawai. Retrieved from https://www.bkn.go.id/wp-content/uploads/2016/05/ PERKA-BKN-NOMOR-3-TAHUN-2016-PEDOMAN-PENYUSUNAN-STANDARTEKNIS-KEGIATAN-SASARAN-KERJA-PEGAWAI.pdf.

[25] Desi, K. and Pangestuti, R. L. (2019). Kiat-Kiat Merangsang Kinerja Karyawan Bagian Produksi. Surabaya: Media Shabat Cendekia.

[26] Koopmans, L., et al. (2013). Measuring Individual Work Performance Identifying and Selecting Indicators. J Prev Assess Rehabil., vol. 3, issue 45, pp. 63-81.

[27] Dhamika, D. (2013). Measuring Employee's Performance in the Public Sector in Sri Lanka: Testing of Two Models. Kelaniya J Hum Resour Magement., vol. 1, issue 8, pp. 1-20.

[28] Noermijati, N. (2013). Kajian Tentang Aktualisasi Teori Hersberg, Kepuasan Kerja dan Kinerja Spiritual Manajer Operasional. Malang: UB Press.

[29] Afandi, P. (2018). Manajemen Sumber Daya Manusia Teori, Konsep dan Indikator. Riau: Zanaf Publishing.

[30] Akinbowale, M. A., Loures, M. E. and Jinabhai, D. C. (2014). Employee Performance Measurement and Performance Appraisal Policy in Organization. Mediterr J Soc Sci., vol. 9, issue 5, pp. 342-7.

[31] Budiarto, S. A. (2017). KPI Key Performance Indicator. Depok: Huta Publisher.

[32] Bhatti, I., Z, Razzaq, A. (2013). The Key Performance Indicators [KPIs] and their Impact on Overall Organizational Performance. Switzerland: Springer Science + Business Media.

[33] Sudarmanto, S. (2009). Kinerja dan Pengembangan Kompetensi SDM: Teori, Dimensi dan Implementasi dalam Organisasi. Yogyakarta: Pustaka Pelajar.

[34] Raja, H. and Gupta, R. (2019). The Impact of Employee Absenteeism on Organizational Productivity with Special Reference to Service Sector. Int J Humanit Arts Lit., vol. 4, issue 7, pp. 581-94.

[35] Mathis, R. L. and Jackson, H. (2009). Manajemen Sumber Daya Manusia. Jakarta: Salemba Empat. 
[36] Saggaf, S. and Akib, H. (2018). Reformasi Pelayanan Publik di Negara Berkembang. Makassar: Sah Media.

[37] Sellang, K., Jamaluddin, A., Mustanir, A. (2017). Strategi dalam Peningkatan Kualitas Pelayanan Publik Dimensi, Konsep, Indikator dan Implementasinya. Pasuruan: Quara Media.

[38] Harry, P. (2014). Langkah Mudah untuk Sukses Berkarir. Jakarta: Elex Media Komputindo.

[39] Princy, K. and Rebeka, K. (2019). Employee Commitment on Organizational Performance. Int J Recent Technol Eng., vol. 3, issue 8, pp. 891-5.

[40] Prihantoro, A. (2019). Peningkatan Kinerja Sumber Daya Manusia melalui Motivasi, Disiplin, Lingkungan Kerja, dan Komitmen. Yogyakarta: Deepublish.

[41] Lee, C-C. and Chen, C. J. (2013). The Relation between Employee Commitment and Job Attitude and its Effect on Service Quality in Tourism Industry. Am J Ind Bus Manag., vol. 3, issue 13, pp. 196-208.

[42] Arifin, A. L. and Yulianti, S. R. (2019). Building Personal Brand Equity. Jakarta: Gramedia.

[43] Kraus, S. and Rigtering, J. P, Hughes, M. (2012). Entrepreneurial Orientation and the Business Performance of SMEs: A Quantitative Study from The Netherlands. J Rev Manag Sci., vol. 1, issue 6, pp. 161-82.

[44] Groen, B. A. C., Wouters, M. J. F. and Celeste, P. (2012). Why do Employees take More Initiatives to Improve their Performance after Co-Developing Performance Measures? A Field Study. Retrieved from https://ris.utwente.nl/ws/portalfiles/portal/ 6591094/Groen12why_preprint.pdf.

[45] Mangkunegara, P.A. (2000). Manajemen Sumber Daya Perusahaan. Bandung: Remaja Rosdakarya.

[46] Shafiah, S. A., Siswidiyanto, S., Prasetyo, W. Y. (2015). Pengaruh Kemampuan dan Motivasi Kinerja Pegawai Kantor Pelayanan Terpadu [studi pada kantor pelayanan terpadu]. J Adm Publik., vol. 2, issue 2, pp. 312-8.

[47] Setiowati, H., Widowati, N. and Mustam, M. (2015). Hubungan Kemampuan dan Motivasi dengan Kinerja Pegawai di Badan Kepegawaian Negara Pusat Jakarta [Studi Kasus di Direktorat Kompensasi Aparatue Sipil Negara]. Retrieved from https://media.neliti.com/media/publications/183482-ID-hubungankemampuan-dan-motivasi-dengan-k.pdf.

[48] Rashid, J. M., et al. (2015). Effectiveness Ways to Motivate People in Organization. Retrieved from https://www.academia.edu/19306802/ Effective_Ways_to_Motivate_Employees_in_an_Organization. 
[49] Sunaryo, S. (2002). Psikologi untuk Keperawatan. Jakarta: EGC.

[50] Susanto, Y. (2017). Peran Kepemimpinan dalam Pengelolahan Koperasi. Yogyakarta: Deepublish.

[51] Fauzi, A. I. (2010). Analisis Faktor yang Mempengaruhi Kinerja Karyawan di Puskesmas Kabupaten Jember. Jember: Universitas Negeri Jember

[52] Masitahsari, U. (2015). Analisis Kinerja Pegawai di Puskesmas Jongaya Makassar. Makassar: Universitas Hasanuddin.

[53] Nofriansyah, D. (2012). Penelitian Kualitatif: Analisis Kinerja Lembaga Pemberdayaan Masyarakat Kelurahan. Yogyakarta: Deepublish.

[54] Nurbaeti, H. H. (2015). Motivasi Kerja Tenaga Kesehatan di Puskesmas Walenrang Kabupaten Luwu. Jurnal Media Kesehatan Masyarakat Indonesia. , pp. 65-70.

[55] Larasati, S. (2018). Manajemen Sumber Daya Manusia. Yogyakarta: Deepublish.

[56] Ratanto, R., Mustikasari, M., Kurtanti, K. (2010). Pengembangan Karies Sebagai Faktor Paling Memengaruhi Kinerja Perawat Pelaksana. J Keperawatan Indones., vol. 2, issue 16, pp. 114-9.

[57] Irawan, P. K. (2016). Hubungan Pengembangan Karir dalam Meningkatkan Kinerj Karyawan di PT.Kawan Era Baru Cabang Bandung. Bandung: Universitas Widyatama.

[58] Distyawati, D. (2017). Pengaruh Kompetensi dan Pengembangan Karir terhdap Kinerja Aparatur Pengawas Inspektorat Daerah Provinsi Sulawesi Tengah. J Katalogis., vol. 4, issue 5, pp. 56-68.

[59] Wijono, S. (2018). Kepemimpinan dalam Prespektif Organisasi. Jakarta: Prenadamedia.

[60] Purwanti, E. and Ayubi, D. (2007). Hubungan Antara Kepemimpinan Kepala Puskesmas dan Karakteristik Petugas dengan Kinerja Petugas Gizi Puskesmas di Kabupaten Karawang Tahun 2007. J Kesehat Masy., issue 2, pp. 164-168.

[61] Fahmi, A., et al. (2014). HRD Syariah Teori dan Implementasi Manajemen Sumber Daya Manusia Berbasis Syariah. Jakarta: Gramedia.

[62] Bismala, L., et al. (2018). Strategi Peningkatan Daya Saing Usaha Kecil Menengah. Medan: Lembaga Penelitian dan Penulisan IImiah Aqli.

[63] Fattah, H. (2017). Kepuasan Kerja \& Kinerja Pegawai. Yogyakarta: Elmatara.

[64] Wahyudi, I. (2012) Penilaian Kinerja Pegawai. Retrieved from https://jatim.kemenag. go.id/file/file/mimbar307/fslx1336001102.pdf.

[65] Terok, G. V., Maramis, F. R. R. and Mandagi, C. K. (2015). Hubungan Kepemimpinan dan Motivasi dengan Kinerja Tenaga Kesehatan di Puskesmas Tuminting Kota 
Manado Tahun 2015. Retrieved from http://medkesfkm.unsrat.ac.id/wp-content/ uploads/2015/08/Jurnal-Gerry-V.A-Terok-1.pdf.

[66] Eastern Illinoins University. (2012). Performance Appraisal Handbook for Civil Service Employees. United States of America: Eastern Illinoins University. 